\title{
Performance Evaluation of Integrated Deep Learning Web Platform for Dataset Training
}

\author{
Sritrusta Sukaridhoto ${ }^{1 *}$, Dwi Kurnia Basuki ${ }^{1}$, Heri Yulianus ${ }^{1,2}$, and Rizqi Putri \\ Nourma Budiarti ${ }^{3}$
}

${ }^{1}$ Politeknik Elektronika Negeri Surabaya, Surabaya

${ }^{2}$ Simpul Technologies, Surabaya

${ }^{3}$ Sistem Informasi, Fakultas Teknik, Universitas Nahdlatul Ulama Surabaya, Surabaya

*Corresponding Author

E-mail: dhoto@pens.ac.id

\begin{abstract}
Along with the complexity of recent web site, many users cannot get the benefits. We developed Integrated Deep Learning Web Platform to help researcher to prepare dataset training for Tensorflow. However, the quality of a web site needs to be assessed. This paper proposes an implementation of WebQual 4.0 for evaluating Integrated Deep Learning Platform for Training Dataset (INDEF) quality. This method used the WebQual model that has some instruments. The instruments grouped the WebQual questions to be three main categories: usability, information and service interaction. From the research conducted can be evaluated that all respondents agreed Integrated Deep Learning Platform for Training Dataset web site met all the WebQual characteristics.
\end{abstract}

Keywords: dataset training, web platform, webqual.

\section{INTRODUCTION}

In recent years, there has been a rapid increase in building an object detection model with Tensorflow Object Detection API [1] for many smart applications. Instead of using a model provided by public dataset, many practitioners made their classifier. A model that is built with Tensorflow Object Detection API needed to pass a few steps to reach the best model. It consists of dataset download, image annotation, label map preparation, TF Record Creation, Pipeline Configuration, OMP Parameter Configuration, Training and Inference. Still, the processes are done with a separated different tool.

The first two steps which we called it dataset preparation is done using an image annotation tool where it's desktop version and not portable. And then the rest, training process, the program and configuration should be built by ourselves. INDEF (Integrated Deep Learning Platform for Training Dataset) provides all of those things and makes it be an integrated system. But, with the complexity of the recent web site, the quality of the website becomes the main goal for users who use it to feel the benefits.

WebQual [2] is a method for evaluating the quality of Web sites, developed by Baner \& Vidgen (2003). WebQual 4.0 is an extended version from WebQual 3.0 where usability replaced site quality categories. WebQual has been used by many researchers and becomes the most popular method for assessing the quality of web sites (Barner \& Vidgen, 2005).

The section in this paper has five purposes: Section 1 present the introduction about background problem, the related works and previous study of the research presents in section 2 . Section 3 offers the methodology of the research was conducted. Section 4 presents the results and discussion of our study. And finally, we closed this paper with Section 5 the conclusion. 
Section 3 offers the methodology of the research was conducted. Section 4 presents the results and discussion of our study. And finally, we closed this paper with Section 5 the conclusion.

\section{RELATED WORKS}

\subsection{TENSORFLOW MACHINE LEARNING DETECTION MODEL}

The study and previous works have developed many models for object detection and machine learning using TensorFlow library. This solution has several steps to do which consist of eight steps: (1) Dataset Download, (2) Image Annotation, (3) Label Map Preparation, (4) TF Record Creation, (5) Pipeline Configuration, (6) OMP Parameter Configuration, (7) Training and (8) Inference. Several applications that used object detection from Tensorflow library and previously they have to create dataset training model in their own computer. The example of Object detection applications are Vehicle as a Mobile Sensor Networks (VaaMSN) [3][4][5], Smart Environment Monitoring and Analytic in Real-time System (SEMAR)[6][7], Classification[8], and also fruit detection[9].

\subsection{INTEgrated DeEP LEARNing Web Platform For DATASET Training}

Integrated Deep Learning Web Platform for Dataset Training (INDEF) is a web application that run on Docker Engine[10]. It consists of several parts such as web service run on NginX webserver[11], Golang RESTful API[12] to control and run Tensorflow engine, Python RESTful API[13] to communicate between WebApps and also mongoDB [14] as a database server. The architecture can be seen on Figure 1.

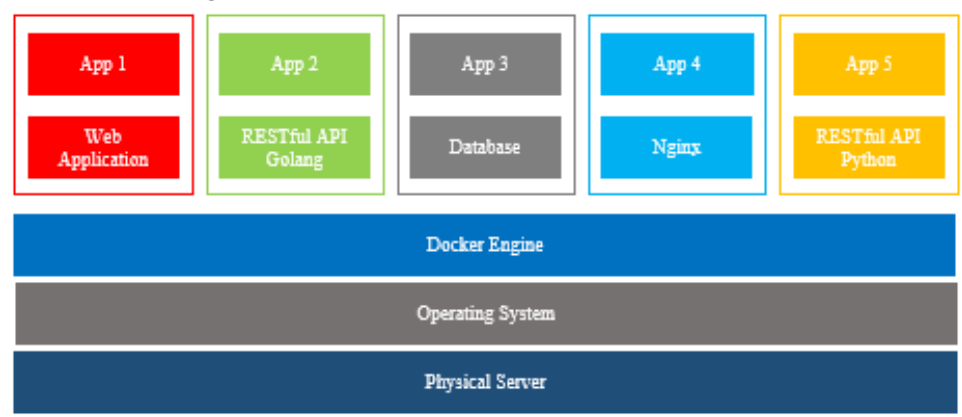

Figure 1. Architecture of Integrated Deep Learning Web Platform.

The process of web platform can be seen on Figure 2. First Data Labeling, this platform is built to give label to each image on dataset for Tensorflow Training process. The interface of data labeling is by draw a box on an image by click and drag the mouse, then user give a text label on that box. Second are Dataset Training, in this process web interface use RESTful API to run Tensorflow training process by Golang and Python scripts. Then the Tensorflow engine will run in the background process and periodically send a log message to a console and read it by web application interface.

Beside controlling the training process, this web platform also provide a management service for user administration, project administration and also batch controlling process. The functional requirement for the web application are: 1) Authentication, 2) Profile, 3) Home, 4) Create Project, 5) Edit, 6) Annotate, 7) Export, 8) Membership, 9) Upload, 10) Generate TFRecord for Tensorflow, 11) Train, 12) Stop, 13) Show Tensorboard, 14) Stop Tensorboard, and 15) Model result. The Functional diagram can be seen on Figure 3. 


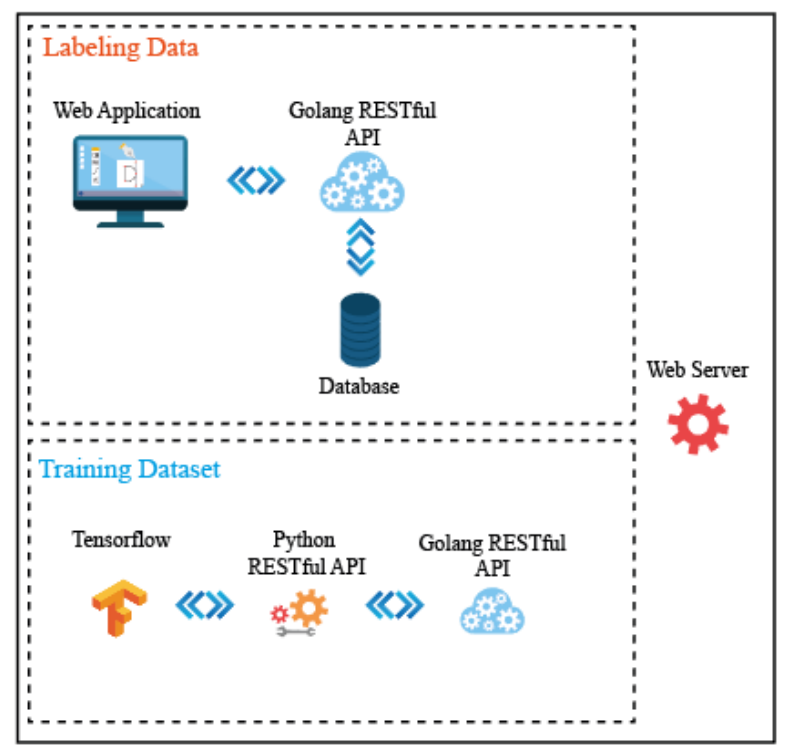

Figure 2. System Detail.

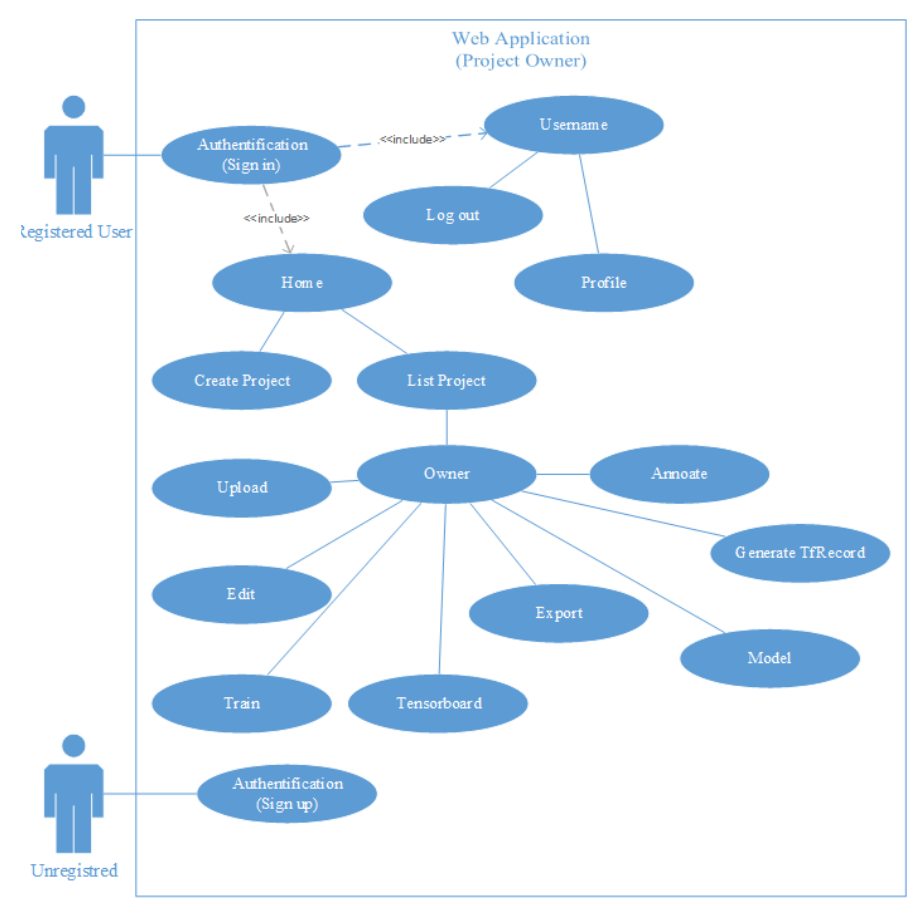

Figure 3. Use case diagram.

\subsection{Measure Web Quality USING WebQuaL}

The previous study show the implementation of WebQual 4.0 as a method for assessing web site quality from the research conducted by Warjiyono and Corie Mei Hellyana explained that WebQual measurement is based on perception from the last user [15]. Meanwhile, the study published by Stuart J. Barnes and Richard T. Vidgen on an integrative approach to the assessment of e-commerce quality shows that this method can build a profile of qualities of an individual web site through WQ index. The quality of each category can be visualized with a radar chart which contains several categories. 


\section{EXPERIMENT}

The key to getting a clear view of the quality of web site, qualitative and quantitative approaches were needed. The screenshot from Integrated Deep Learning Platform for Training Dataset can be seen from Figure 4 until Figure 10.

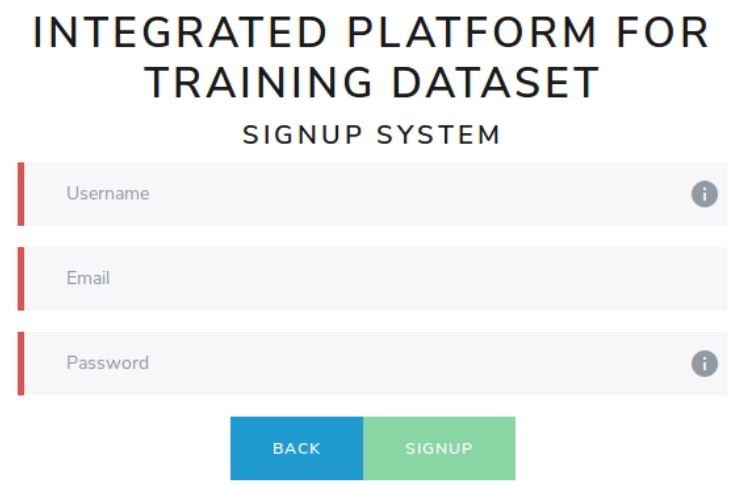

Figure 4. Signup form.

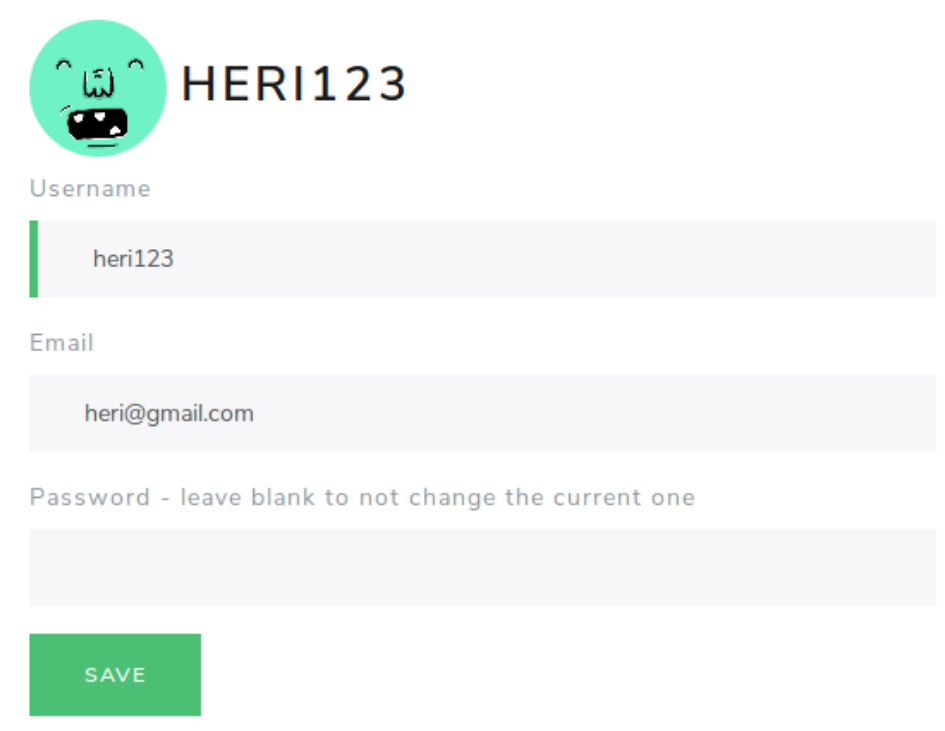

Figure 5. Profile page. 


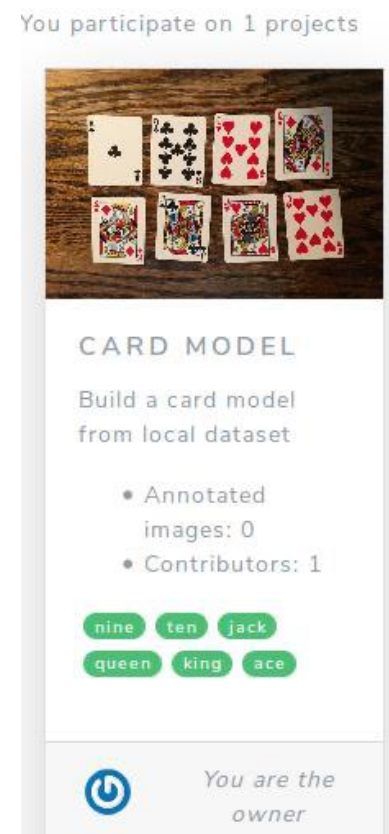

Figure 6. Project menu.

\section{CREATE PROJECT}

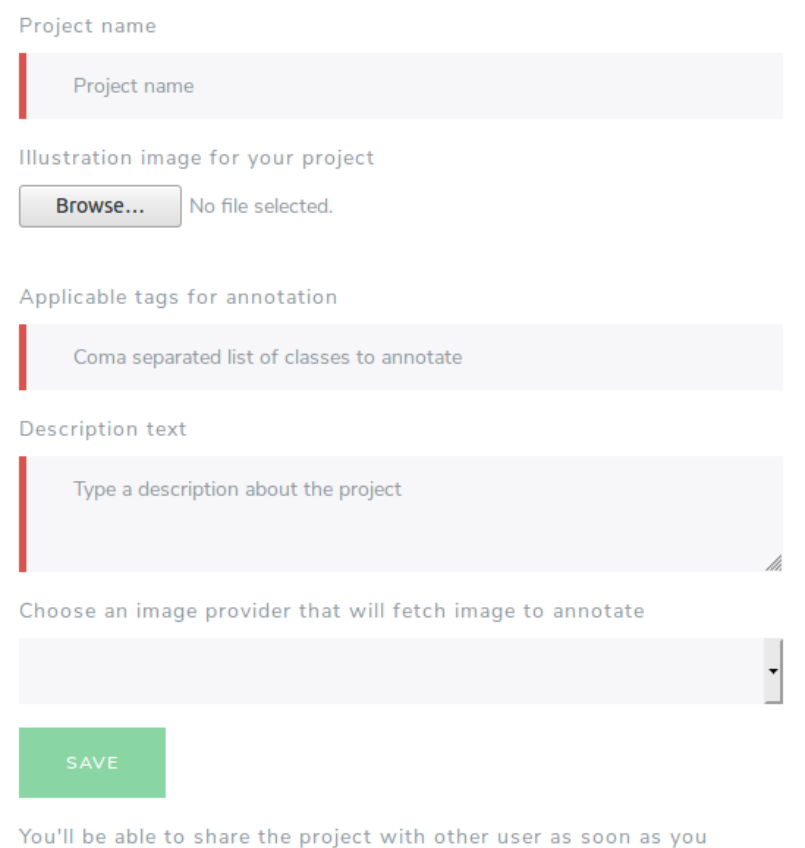

Figure 7. Create Project. 


\section{EDIT PROJECT}

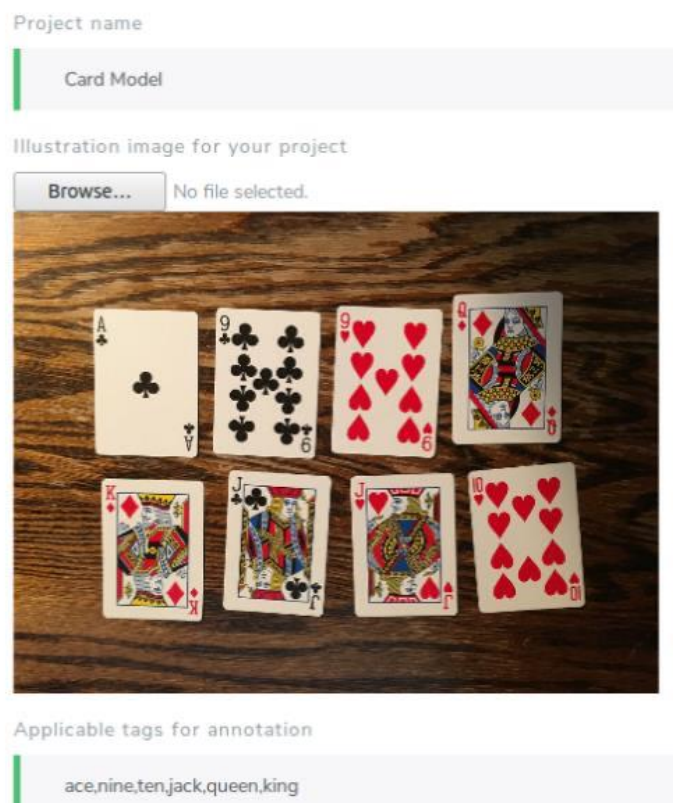

Figure 8. Edit Project.
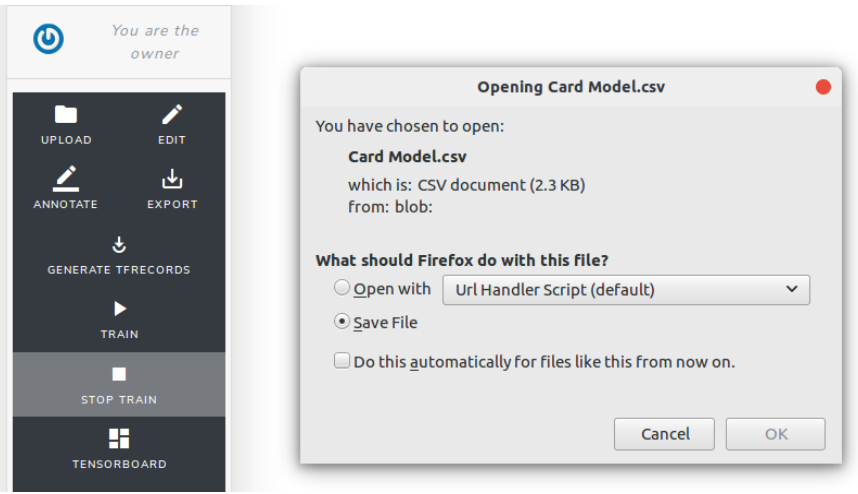

Figure 9. Export model from dataset training and Tensorflow training controls.
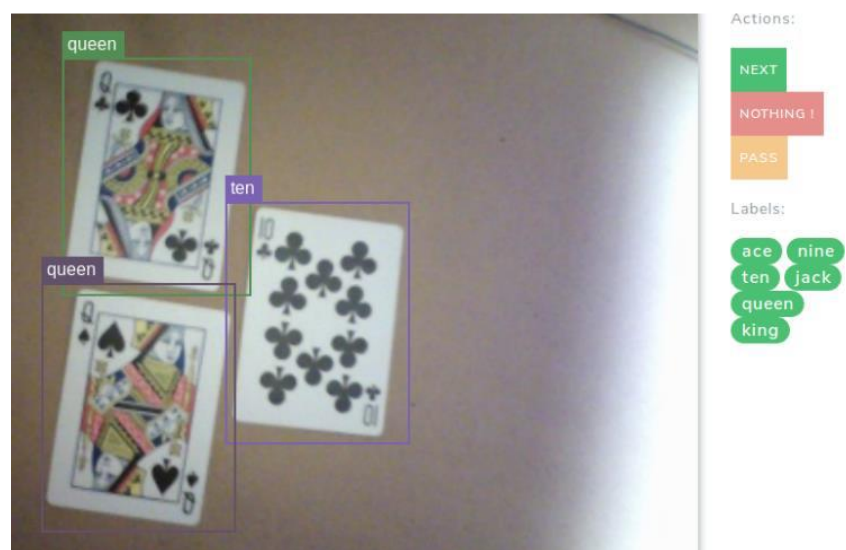

Figure 10. Annotate - dataset labeling.

However, WebQual was adopted. The model of WebQual used is about getting the primer data from survey through a questionnaire. This survey can be achieved, whether it's offline or online. This research used the WebQual model, which consists of three instruments; usability, 
information and service interaction. The questionnaire was designed using google form and Likert scale. The questionnaire questions translated to Bahasa and distributed to 30 people who used the INDEF Platform. The WebQual 4.0 categories and questions can be seen as shown in Table 1 .

Table 1. The instrument of WebQual 4.0 (source: Barnes and Vidgen, 2000).

\begin{tabular}{|c|c|c|}
\hline Category & WebQual 4.0 Questions & Code \\
\hline \multirow[t]{7}{*}{ Usability } & Is easy to use & USA1 \\
\hline & Has things where you expect to find them & USA2 \\
\hline & Is easy to find your way around & USA3 \\
\hline & Has fast navigation to pages & USA4 \\
\hline & Has useful links to other sites & USA5 \\
\hline & Is easy to find & USA6 \\
\hline & Facilitates return visits & USA7 \\
\hline \multirow[t]{12}{*}{ Information } & Has an attractive appearance & INF1 \\
\hline & Has an appropriate style of design for site type & INF2 \\
\hline & Provides quick and easy access to finding information & INF3 \\
\hline & Provides relevant information & INF4 \\
\hline & Provides information at an appropriate level of detail & INF5 \\
\hline & Provides information content that is easy to read & INF6 \\
\hline & Communicates information in an appropriate format & INF7 \\
\hline & Provides information content that is easy to understand & INF8 \\
\hline & Has information that is updated regularly & INF9 \\
\hline & Has reliable information & INF10 \\
\hline & Has reasonable loading time & INF11 \\
\hline & Creates an experience & INF12 \\
\hline \multirow{5}{*}{$\begin{array}{c}\text { Service } \\
\text { Interaction }\end{array}$} & Conveys a sense of community & SER1 \\
\hline & Keeps the user's attention & SER2 \\
\hline & Is a site that feels secure & SER3 \\
\hline & Makes it easy to give feedback & SER4 \\
\hline & Makes it easy to contact the organization & SER5 \\
\hline
\end{tabular}

We run our web application on LAN 1Gbps and 802.11ac WLAN, we used server with specification Xeon 48 Core CPU, 96 GB RAM, NVIDIA GTX1060 GPU, and 3TB HDD. On the clients side, users used i5 CPU with 4GB with Chrome Browser web client.

In the Figure 11 shows that the different between labelling tool from labelimg[16] application and labelling from Integrated platform. The conventional way is labelimg, user have to create dataset label in their PC and re-manage all the images and send all the data to Tensorflow server or PC, but with our platform all of images already in the server and user able to directly run Tensorflow engine from web interface. 


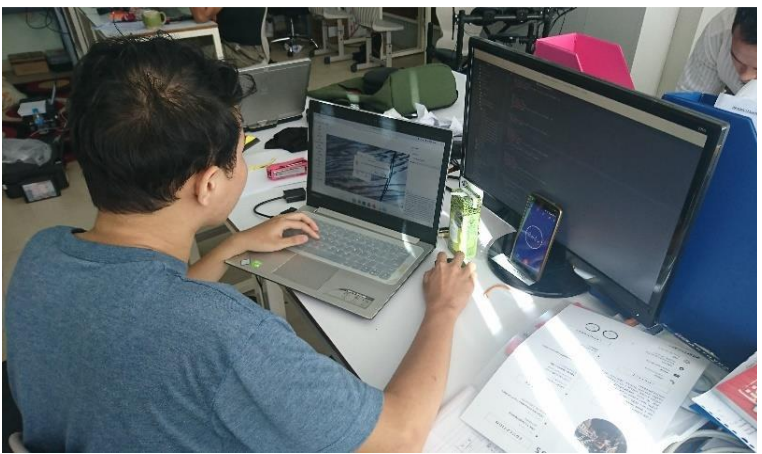

(a)

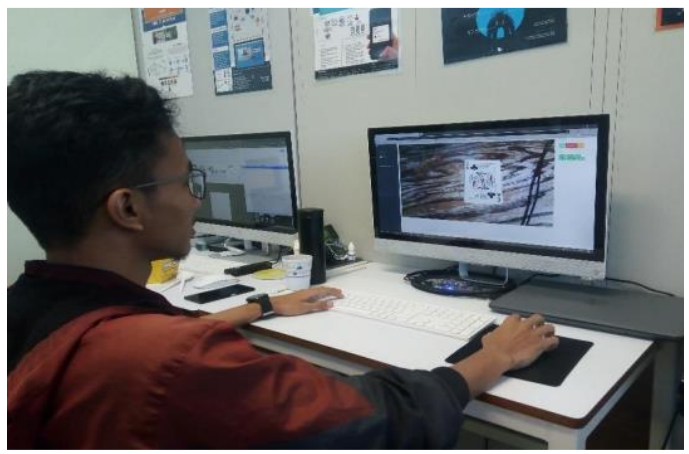

(b)

Figure 11. Implementations: (a) using labelimg, (b) using INDEF Platform.

\section{RESULT AND DISCUSSION}

The data that was taken from questionnaire is qualitative data, and for the result, descriptive approached is used. The next step is to examine whether the factors are valid or not in order to measure the construction. In the measurement points above, maybe there is a point that not valid or reliable. Therefore, it should be removed or replaced by other questions. Validation is done by looking at a corrected item-total correlation in the analysis factor. Corrected item-total correlation number was from product-moment correlation between each question that will be test and sum of questions.

Table 2. WebQual questioner results.

\begin{tabular}{|c|c|c|c|c|c|c|}
\hline \multirow[b]{2}{*}{ Code } & \multirow[b]{2}{*}{ WebQual Questions } & \multicolumn{5}{|c|}{ Result (\%) } \\
\hline & & $\begin{array}{l}\text { Strongly } \\
\text { Disagree }\end{array}$ & Disagree & Neutral & Agree & $\begin{array}{l}\text { Strongly } \\
\text { Agree }\end{array}$ \\
\hline USA1 & Is easy to use & 3.3 & 3.3 & 6.7 & 73.3 & 13.3 \\
\hline USA2 & $\begin{array}{l}\text { Has things where you } \\
\text { expect to find them }\end{array}$ & 0 & 0 & 23.3 & 53.3 & 23.3 \\
\hline USA3 & $\begin{array}{l}\text { Is easy to find your } \\
\text { way around }\end{array}$ & 0 & 3.3 & 20 & 70 & 6.7 \\
\hline USA4 & $\begin{array}{l}\text { Has fast navigation to } \\
\text { pages }\end{array}$ & 0 & 0 & 10 & 63.3 & 26.7 \\
\hline USA5 & $\begin{array}{l}\text { Has useful links to } \\
\text { other sites }\end{array}$ & 0 & 3.3 & 23.3 & 60 & 13.3 \\
\hline USA6 & Is easy to find & 0 & 0 & 23.3 & 56.7 & 13.3 \\
\hline USA7 & Facilitates return visits & 0 & 6.7 & 16.7 & 63.3 & 13.3 \\
\hline INF1 & $\begin{array}{l}\text { Has an attractive } \\
\text { appearance }\end{array}$ & 0 & 0 & 6.7 & 3.3 & 26.7 \\
\hline INF2 & $\begin{array}{l}\text { Has an appropriate } \\
\text { style of design for site } \\
\text { type }\end{array}$ & 0 & 0 & 10 & 66.7 & 23.3 \\
\hline INF3 & $\begin{array}{l}\text { Provides quick and } \\
\text { easy access to finding } \\
\text { information }\end{array}$ & 0 & 0 & 10 & 76.7 & 13.3 \\
\hline
\end{tabular}




\begin{tabular}{|c|c|c|c|c|c|c|}
\hline INF4 & $\begin{array}{l}\text { Provides relevant } \\
\text { information }\end{array}$ & 0 & 0 & 16.7 & 76.7 & 6.7 \\
\hline INF5 & $\begin{array}{l}\text { Provides information at } \\
\text { an appropriate level of } \\
\text { detail }\end{array}$ & 0 & 0 & 26.7 & 56.7 & 16.7 \\
\hline INF6 & $\begin{array}{l}\text { Provides information } \\
\text { content that is easy to } \\
\text { read }\end{array}$ & 0 & 0 & 10 & 76.7 & 13.3 \\
\hline INF7 & $\begin{array}{l}\text { Communicates } \\
\text { information in an } \\
\text { appropriate format }\end{array}$ & 0 & 0 & 16.7 & 50 & 26.7 \\
\hline INF8 & $\begin{array}{l}\text { Provides information } \\
\text { content that is easy to } \\
\text { understand }\end{array}$ & 0 & 0 & 26.7 & 73.3 & 13.3 \\
\hline INF9 & $\begin{array}{l}\text { Has information that is } \\
\text { updated regularly }\end{array}$ & 0 & 3.3 & 30 & 46.7 & 20 \\
\hline INF10 & $\begin{array}{l}\text { Has reliable } \\
\text { information }\end{array}$ & 0 & 0 & 30 & 53.3 & 16.7 \\
\hline INF11 & $\begin{array}{l}\text { Has reasonable loading } \\
\text { time }\end{array}$ & 0 & 3.3 & 23.3 & 53.3 & 20 \\
\hline INF12 & Creates an experience & 0 & 3.3 & 16.7 & 56.7 & 23.3 \\
\hline SER1 & $\begin{array}{l}\text { Conveys a sense of } \\
\text { community }\end{array}$ & 0 & 0 & 23.3 & 53.3 & 23.3 \\
\hline SER2 & $\begin{array}{l}\text { Keeps the user's } \\
\text { attention }\end{array}$ & 0 & 3.3 & 16.7 & 66.7 & 13.3 \\
\hline SER3 & $\begin{array}{l}\text { Is a site that feels } \\
\text { secure }\end{array}$ & 0 & 0 & 20 & 66.7 & 6.7 \\
\hline SER4 & $\begin{array}{l}\text { Makes it easy to give } \\
\text { feedback }\end{array}$ & 0 & 0 & 40 & 53.3 & 6.7 \\
\hline \multirow[t]{2}{*}{ SER5 } & $\begin{array}{l}\text { Makes it easy to } \\
\text { contact the } \\
\text { organization }\end{array}$ & 0 & 13.3 & 20 & 56.7 & 10 \\
\hline & SUM-AVG= & 0,14 & 1,80 & 19,45 & 59,45 & 16,25 \\
\hline
\end{tabular}

As shown in Table 2, the average of strongly disagree and disagree are $0.14 \%$ and $1.8 \%$ it means that very small number that users doesn't agree. And for neutral average is $19.45 \%$. The percentage for agree and strongly agree are $59.45 \%$ and $16.25 \%$, it means that more than $75 \%$ users are agree. Therefore, the highest score is agreed.

It can be seen from Error! Reference source not found. that all the questions were grouped into three categories. The average of 24 question responses above, the results can be seen in Figure 12. 


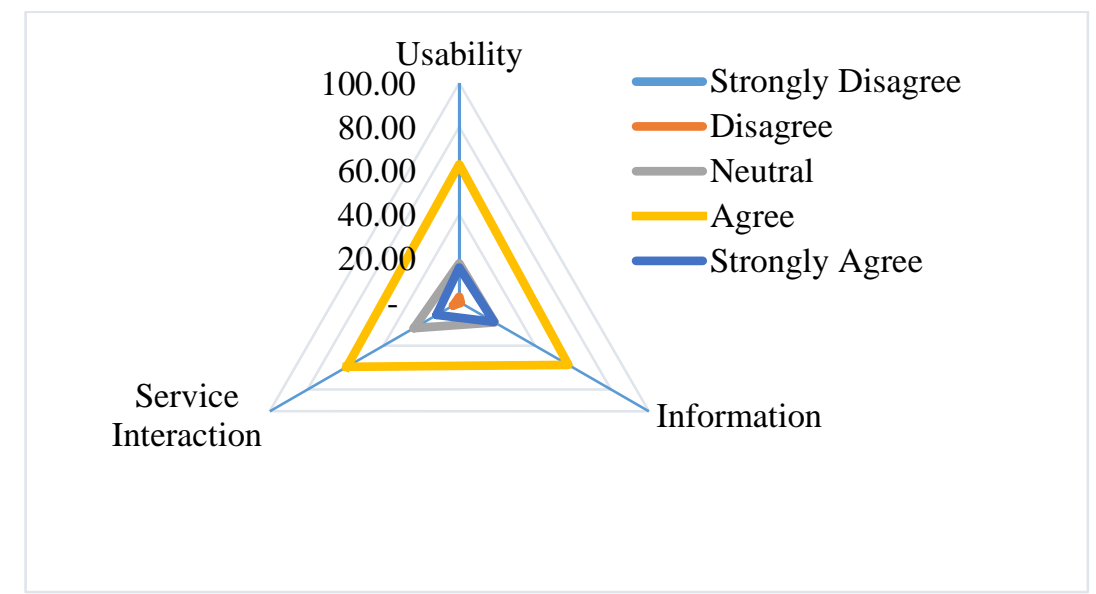

Figure 12. Results of measurement from Webqual 4.0 questioner

\section{CONCLUSION}

Based on Table 2 and Figure 12 can be concluded that all respondents agreed Integrated Deep Learning Platform for Training Dataset met all WebQual characteristics, which are usability, information quality and service interaction.

\section{REFERENCES}

[1] M. Abadi et al., "TensorFlow: A System for Large-Scale Machine Learning," in 12th \{USENIX\} Symposium on Operating Systems Design and Implementation (\{OSDI\} 16), 2016, pp. 265-283.

[2] S. Barnes and R. Vidgen, "Association for Information Systems AIS Electronic Library (AISeL) WebQual: An Exploration of Website Quality Recommended Citation WebQual: An Exploration of Web-site Quality," 2000.

[3] Y. Yohanie et al., "Implementation of Integration VaaMSN and SEMAR for Wide Coverage Air Quality Monitoring," TELKOMNIKA, vol. 16, no. 6, pp. 2630-2642, 2018.

[4] A. M. R. Ulil, S. Sukaridhoto, A. Tjahjono, D. K. Basuki, and others, "The Vehicle as a Mobile Sensor Network base IoT and Big Data for Pothole Detection Caused by Flood Disaster," in IOP Conference Series: Earth and Environmental Science, 2019, vol. 239, no. 1, p. 12034.

[5] A. Rasyid et al., "Pothole Visual Detection using Machine Learning Method integrated with Internet of Thing Video Streaming Platform," in 2019 International Electronics Symposium (IES), 2019, pp. 672-675.

[6] Y. Y. Fridelin, M. R. U. Albaab, A. R. A. Besari, S. Sukaridhoto, and A. Tjahjono, "Implementation of Microservice Architectures on SEMAR Extension for Air Quality Monitoring," in 2018 International Electronics Symposium on Knowledge Creation and Intelligent Computing (IES-KCIC), 2018, pp. 218-224.

[7] R. Arridha, S. Sukaridhoto, D. Pramadihanto, and N. Funabiki, "Classification extension based on IoT-big data analytic for smart environment monitoring and analytic in real-time system," Int. J. Space-Based Situated Comput., vol. 7, no. 2, pp. 82-93, Jan. 2017.

[8] R. P. N. Budiarti, S. Sukaridhoto, M. Hariadi, and M. H. Purnomo, "Big Data Technologies using SVM (Case Study: Surface Water Classification on Regional Water Utility Company in Surabaya)," in 2019 International Conference on Computer Science, Information Technology, and Electrical Engineering (ICOMITEE), 2019, pp. 94-101.

[9] H. Basri, I. Syarif, S. Sukaridhoto, and M. F. Falah, "INTELLIGENT SYSTEM FOR AUTOMATIC CLASSIFICATION OF FRUIT DEFECT USING FASTER REGIONBASED CONVOLUTIONAL NEURAL NETWORK (FASTER R-CNN)," Kursor, vol. 10, no. $1,2019$. 
[10] S. Kum, Y. Kim, and J. Moon, "Deploying Deep Neural Network on Edge-Cloud environment," in 2019 International Conference on Information and Communication Technology Convergence (ICTC), 2019, pp. 242-244.

[11] C. Nedelcu, Nginx HTTP Server: Adopt Nginx for Your Web Applications to Make the Most of Your Infrastructure and Serve Pages Faster Than Ever. Packt Publishing Ltd, 2010.

[12] M. Andrawos and M. Helmich, Cloud Native Programming with Golang: Develop microservice-based high performance web apps for the cloud with Go. Packt Publishing Ltd, 2017.

[13] T. Ziade, Python Microservices Development. Packt Publishing Ltd, 2017.

[14] D. Vohra, "Using MongoDB Database," in Kubernetes Microservices with Docker, Springer, 2016, pp. 167-200.

[15] W. Warjiyono and C. M. Hellyana, "Pengukuran Kualitas Website Pemerintah Desa Jagalempeni Menggunakan Metode Webqual 4.0," J. Teknol. Inf. Dan Ilmu Komput., vol. 5, no. 2, p. 139, 2018.

[16] D. Tzutalin, "Labelimg." 2018. 